\title{
Russia's Strategy in Sub-Saharan Security in the Wake of the Ukraine Crisis
}

\section{Alba Iulia Catrinel Popescu ${ }^{1}$}

\begin{abstract}
:
Stung by the West's economic sanctions because of its role played in triggering and maintaining the present crisis in Ukraine, the Russian Federation is looking for solutions to help maintain its energy dominance of Europe and extend its economic, military, political and diplomatic strength.

In this context, Africa's resources, upon which the international economic system depends, are in play. How will the West counteract Russia's increasingly aggressive penetration in Sub-Saharan countries which were traditionally in the West's sphere of influence? How will China react? Are we going to witness an understanding between the BRICS and the West relating to a new division of Africa? Will there be new conflicts?
\end{abstract}

Keywords: Ukrainian Crisis, Trans-Sahara Gas Pipeline, NIGAZ, NDB, AFROCOM, BRICS.

\footnotetext{
${ }^{1}$ National Defense University “CAROL I”, albatanasescu@hotmail.com
} 


\section{Introduction}

During September 2014, two news items have exploded in the Nigerian press. Australian negotiator Stephen Davis ${ }^{2}$ has accused people from current President Goodluck Jonathan entourage of funding the terrorist organization Boko Haram, ${ }^{3}$ while Nigerian intelligence sources claimed that Nigerian soldiers are being trained by the Russian Federation and that the Nigerian federal government has decided to buy Russian weaponry as traditional Western allies have failed to fully support Nigeria's against the insurgency of Boko Haram ${ }^{4}$. On the other hand, since August 2014, the alarm was sounded over on the Russian diplomatic and economic offensive in Africa which was intended to secure energy transport networks to Europe and dominate regions rich in strategic resource fields.

Stung by the Westerners' economic sanctions because of the role played in triggering and maintaining present crisis in Ukraine, the Russian Federation is looking for solutions to help maintain Moscow's energy advantages and preserve its economic, military, political and diplomatic strength. How will the West counteract Russia's increasingly aggressive penetration in Sub-Saharan countries which were traditionally in the West's sphere of influence? Will China accept BRICS transformation into a vehicle to serve Russia's geopolitical interests? Will the BRICS transform into a new Non-Aligned Movement with Russia as a flag bearer? Are we going to witness an understanding between the BRICS and the West relating to a new division of Africa? Will there be new conflicts?

\section{A Revisionist Russian Federation and African Gas Stake}

The Russian Federation's strategy for reaffirming itself as a great power has been based on two cards that are being played against the West: Europe's energy dependence on Russian gas, and emerging nation diplomatic support in the UN Security Council in matters such as Afghanistan, Iran and North Korea, as well as the international space program or agreements on strategic and conventional weapons.

The Ukrainian crisis has awakened the West to Moscow's true intentions of rebuilding the former Soviet Empire. Even if there weren't already so very clear

\footnotetext{
${ }^{2}$ Powell G., Australian Stephen Davis risked life in attempt to rescue kidnapped Nigerian girls, 27.08.2014, ABC NEWS, http://www.abc.net.au/news/2014-08-27/australian-risks-lifeto-rescue-kidnapped-nigerian-girls/5699676, accessed on 20.09.2014.

${ }^{3}$ Exposing the CBN Boko Haram "sponsor", Vanguard, 19.09.2014,

http://www.vanguardngr.com/2014/09/exposing-cbn-boko-haram-sponsor/, accessed on 20.09.2014.

${ }^{4}$ Agande, B., BOKO HARAM: FG turns to Russia, China as USA, UK fail Nigeria, Vanguard, 20.09.2014, http://www.vanguardngr.com/2014/09/boko-haram-fg-turns-russia-china-usa-ukfail-nigerial, accessed on 20.04.2014.
} 
signals, suffice it to say the Georgian ${ }^{5}$ crisis in 2008, the period since the dismantling of the Soviet Union was characterized by Western passivity toward the steps the Kremlin took in order to achieve that reconstruction. Russia was tolerated when she generated and maintained the so-called frozen conflicts in the former Soviet Union, when she infiltrated the internal economic, financial and political affairs of Europe, and when she fractured the common European energy policy regarding the construction of the Nabuco gas pipeline.

NATO Secretary General, Anders Fogh Rasmussen, emphasized at the September 2014 Allied Summit that a revisionist Russia "has shown that it is willing to use all means, including force, to extend its influence and control over independent sovereign nations in blatant disregard of international law" which is why we assist to "a fundamentally new security situation in Europe" that requires a reshaping of Euro-Atlantic security in the next decade, in other words, the adoption of a new strategic concept. It is obvious that the annexation of the Crimea peninsula and the hybrid war tactics used in Ukraine have shrunk and diluted the soft power tools used by the Russian Federation in the relationship with the West.

What can Russia do in this context? Russia has Europe in an economic vice predicated on European dependence on Russian energy, she stimulates all kinds of disputes within the European Union using extremists, revisionists, and representatives of Euro-skeptic political parties, she promotes her views and interests through obedient media institutions to divide and rule Europe. How important is the control of alternative energy sources to Europe? In a word, vital.

In 2009, right after the Georgian crisis, Russian President Dmitry Medvedev visited several African countries in a diplomatic tour aimed at rebuilding Moscow's dominance in the region and to accelerate trade in hydrocarbons, rare earth metals REM, uranium, diamonds, ferrous and non-ferrous ores ${ }^{6}$. The diplomatic tour included Nigeria - the largest oil producer in Africa and owner of untapped natural gas deposits, as well as iron ore, coal, uranium and REM; Angola - oil and diamonds producer; Zimbabwe - one of the largest global producers of platinum and diamonds, and Egypt, a former ally and holder of oil, natural gas, uranium and REM ores.

In 2005, Nigerian officials, along with those of Niger and Algeria joined in the New Partnership for African Development Initiatives (NEPAD), started construction of a Trans-Saharan pipeline meant to supply Europe with Nigerian gas. The pipeline,

\footnotetext{
${ }^{5}$ Presa rusă: criza georgiană a pus punct relațiilor amicale dintre Rusia și SUA, Infomondo, http://www.infomondo.ro/presa-rusa-criza-georgiana-a-pus-punct-relatiilor-amicale-dintrerusia-si-sua-2556.html, accessed on 21.09.2014.

${ }^{6}$ Cohen A., Russia's New Scramble for Africa, Moscow attempts to rebuild its sphere of influence in the African continent. Wall Street Journal Europe, 02.07.2009,

http://online.wsj.com/article/SB124639219666775441.html, accessed on 20.09.2014.
} 
with a length of $4,128 \mathrm{~km}$, was to be built and operated by the Nigerian National Petroleum Corporation, NNPC, and Sonatrach Algerian National Oil Company in order to transport gas from the Nigerian Delta State to the Algerian terminals El Kala and Beni Şaf on the Mediterranean $\mathrm{Sea}^{7}$, and from there, through TransMaghreb-Europe, Mediterranean, Medgaz, and Galsi pipelines to the Spanish and European distribution network. Completion date for this project is scheduled for 2015 at a total cost of $\$ 12$ billion.

Major companies in the energy field like Total SA, Royal Dutch Shell, Eni and GAIL have declared an interest in this huge strategic and business opportunity. In this context, during President Medvedev's visit to Nigeria, an agreement between the Russian and the Nigerian Government was signed creating a joint venture with equal shares held by Gazprom and NNPC. The venture, named NIGAZ, saw the Russians assume responsibility for the construction of the $1,037 \mathrm{~km}$ Nigerian segment of the Trans-Saharan pipeline. This agreement represented a real blow to Europe. If the project will be successful, the Russians will be able to manipulate the gas flow buttons efficiently when geopolitical interests require it. If the project will fail, the Russians will win again, because the African gas will not fill the European pipelines.

It appears the artisan of this agreement is Rilwanu Lukman, PhD, a Gazprom International employee since after the period when he was Minister of Petroleum in the Nigerian Government. He is also co-founder of Afren Plc, a Gazprom business partner with whom it shares the responsibilities and the benefits of this agreement ${ }^{8}$. The same Dr. Lukman, who was the Adviser on Strategic Issues and Energy of the President Yar'Adua, seems to have convinced state authorities to sign an agreement facilitating Russian-Nigerian exploitation of uranium ores, Nigeria being the holder of the seven percent of global uranium reserves. On the 4th of June 2012, in Moscow an agreement was signed between the Russian state-owned company, Rosatom, and the Nigerian Nuclear Regulatory Agency, the NNRA, to construct a nuclear power plant in Nigeria, the second in Africa since the Russians built the Koeberg nuclear plant in the South African Republic in $1984^{9}$.

On the 19th of September 2014, Nigerian mass media published a statement from the Australian negotiator Dr. Stephen Davis charging that the former Chief of the General staff of the Nigerian Army Lieutenant General Azubuike Ihejirika, a still unnamed high official of the Central Bank of Nigeria CBN, and Ali Modu Sheriff, a

\footnotetext{
${ }^{7}$ NNPC: a pipeline of opportunities, Pipelines International, Iunie 2010, http://pipelinesinternational.com/news/nnpc_a_pipeline_of_opportunities/041509/, accessed on 11.01.2012.

${ }^{8}$ Folawiyo Y., Nigeria in a lame trans-Saharan gas pipeline deal with Gazprom, Money Worth, http://www.money worth.com.ng/nigeria-in-a-lame-trans-saharan-gas-pipeline-dealwith-gazprom/, accessed on 23.09.2014.

${ }^{9}$ Rosatom signs international deals, 04.06.2012, world nuclear news, http://www.worldnuclear-news.org/NN_Rosatom_signs_international_deals_0406121.html, accessed on 23.09.2014.
} 
former Governor of Borno State (who was also an intimate of the current president, Goodluck Jonathan), are among the sponsors of the terrorist group Boko Haram. Dr Davis' statement is supported by the 1986 Nobel Laureate for literature, Wole Soyinka ${ }^{10}$. This very strong accusation concerning the Nigerian Central Bank's involvement in money laundering operations for the benefit of a terrorist organization that threaten the state's stability must be looked at in a broader context. On the 20th of September 2014, in the Nigerian press disseminated another very interesting report the source of which was the Nigerian Secret Service. It stated that alleged Nigerian officials have decided to turn to Russian and Chinese expertise to fight Boko Haram after traditional Western allies failed to support the struggle against the insurgency. Consequently, staff belonging to the army, police, state security service SSS, are being trained in counterterrorism in the Russian Federation and, once training is concluded, will constitute the Nigerian Special Forces Brigade. Furthermore, Nigerian officials have decided to purchase heavy weaponry and logistics from Russia charging the West has refused to offer their support in this area as well, according to sources in the Nigerian Secret Service.

Starting in 2009, Boko Haram initiated attacks on representative institutions of state power marking a new stage in its evolution as a terrorist organization from an extremist group with anarchist-type events designed to destabilize and to create anxiety in the target population, to an organization of a political and military type that espouses a political program to set up an Islamic State, to purge Nigeria of all that does not belong to Islamic culture and civilization, and that organizes its actions following rules of military planning. This evolution, coupled with the end of the good relations between Russia and its western partners following the Georgian crisis, plus the current reports about Russian military and logistics expertise provided to the Nigerians as a result of a purported lack of Western support against interest the Boko Haram insurgency begins to gain new dimensions. The situation is more complicated whereas Nigeria is one of the pillars of the West in Sub Saharan region, is the largest African market with one-quarter of the total population of the Sub-Sahara, acquires an army listed among the best of the whole Sub Saharan region and a consistently strong political-diplomatic influence both in the African Union and regional organizations.

Another point of attraction for the Kremlin is Algeria, the third largest supplier of natural gas to Europe after Russia and Norway, and the second natural largest gas producer on the African continent. Assis Malaquias, expert in economic defense at Africa Center for Strategic Studies in Washington, D.C., stated that, in 2015, Russia will reach an average of $40 \%$ control of the supply of gas in Europe because of her penetration in North African gas producer states, and he warned Spain and Italy about the possibility of losing alternative sources of supply from Algeria and

\footnotetext{
${ }^{10}$ Exposing the CBN Boko Haram "sponsor", Vanguard, 19.09.2014, http://www.vanguardngr.com/2014/09/exposing -cbn-boko-haram-sponsor/, accessed on 24.09.2014.
} 
Egypt $^{11}$. Energy dependence on Russia represents a limiting factor on the ability of Europeans to react in sensitive matters such as Ukraine, Syria or in potential further developments in the Republic of Moldavia. According to the Stockholm International Peace Research Institute, during 2003-2012 the volume of Algerian government expenditure for the acquisition of Russian weaponry and military equipment has reached $91 \%$ of a total of $\$ 54$ billion budget and representing $10 \%$ of the total Russian military exports ${ }^{12}$. This special military cooperation started during the Cold War when the Soviet Union was the first state to recognize Algeria's independence from French domination and continued as Moscow was the main partner in rebuilding the country after the independence war. In 2009, in eastern Algeria, the Algerian-Russian El Assel Project for exploration and production of crude oil and natural gas was initiated with Sonatrach owning $51 \%$ of the shares and the remaining $49 \%$ belonging to Gazprom International ${ }^{13}$. During February 2014, Gazprom International was officially invited by Sid Ali Betata, president of the National Agency for the Development of Hydrocarbon Resources ALNAFT, to participate in the international tender for the exploration and exploitation of 30 new potential gas deposits plots, representing $19 \%$ of Algerian territory ${ }^{14}$.

The SAR, a bastion of Western culture in Sub Saharan Africa, signed an agreement of strategic partnership in nuclear energy with the Russian Federation, in September 2014. The $\$ 10$ billion agreement provides for the construction by Rosatom of eight nuclear reactors, with a capacity of $9.6 \mathrm{GW}$ by the end of 2030 . These new production capacities will compliment two other nuclear reactors already in operation at the nuclear power station at Koeberg accounting for six percent of the total domestic electricity demand of the $\mathrm{SAR}^{15}$.

Russian interests are not confined to fields of energy or exports of weapons. African deposits of chromium, mercury, manganese, aluminum, REM, copper, zinc, nickel, and the mines for diamonds and platinum are targeted, too. Now Russia imports $100 \%$ of their domestic consumption of manganese, $80 \%$ of their chromium needs and $60 \%$ of bauxite, a large part of the latter from Guinee. According to the African

\footnotetext{
${ }^{11}$ Neuhauser A., With World Watching Ukraine, Russia Makes Energy Moves in Africa,U.S.News\&WORLD REPORT, 25.04.2014, http://www.usnews.com/news/articles/2014/04/25/with-world-watching-ukraine-russia-makesenergy-moves-in-africa, accessed on 20.09.2014.

${ }^{12}$ Neuhauser A., op.cit.

${ }^{13}$ In Algeria, drilling work on the new well begins, Gazprom International, 18.06.2014, http://www.zargaz.ru/ en/news-media/articles/algeria-drilling-work-new-well-begins, accessed on 20.09.2014.

${ }^{14}$ Visit of Gazprom International Head to Algeria, Gazprom International, 07.02.2014, http://www.zargaz.ru/ en/news-media/articles/visit-gazprom-international-head-algeria, accessed on 21.04.2014.

${ }^{15}$ Phillips A., South Africa and Russia sign Multi-Billion Rand Nuclear Reactor Deal, 25.09.2014 http://www.africanbusinessreview.co.za/technology/1689/South-Africa-andRussia-Sign-Multi-Billion-Rand-Nuclear-Reactor-Deal, accessed on 27.09.2014.
} 
Development Bank, in 2013, Russian companies invested in Africa around \$ 20 billion in the production of energy, mineral-extracting industries, fishing and agriculture. In 2009, the Coordination Committee on Economic Cooperation with African Countries, AFROCOM ${ }^{16}$ was created, as a body which brings together, under the leadership of the president of the Russian state-owned bank Vnesekonombank, various ministries, government agencies, economic agents interested in the African market. This committee collaborates with the Russian Agency for Export Credit and Investment Insurance EXIAR ${ }^{17}$ that was created in 2011 with the aim of protecting investors who enter the market from political and military risks. Creating such an agency demonstrates the Kremlin's determination to rebuild its influence and to take control of the Sub Saharan region.

In this respect, a sample of strategic thinking represents the 2012 Russian governmental decision to delete $\$ 20$ billion of historical debt of African states initiated during the period of the USSR and subsequently transferred to the Russian Federation $^{18}$. This decision is one of many in 2008, when Moscow canceled another $\$ 16$ billion in debt owed by the same countries. In addition, Russia has announced the transfer of $\$ 50$ million to the World Bank Foundation for the Poor with the aim of developing regions located in Sub Saharan Africa and has granted more than 8,000 places in its own universities for young Africans, of which 4,000 are study grants. Russia has signed agreements with Zambia and Tanzania through which the value of debts canceled will be used for development in those two states. Other similar agreements are to be concluded with Ethiopia, Mozambique and Benin. These states are not altruistically chosen. There are large deposits of REM in Zambia, Tanzania and Mozambique, and some countries are in the immediate vicinity of geostrategic targets, as well as Ethiopia, Tanzania, Benin, Mozambique, the latter additionally holding large deposits of natural gas.

In the first half of 2014, in Moscow, a series of meetings was held between highranking Russian officials and their counterparts in Algeria, Angola, Egypt, Mauritania, Morocco, Mozambique, Eritrea, Uganda, Zimbabwe, Sudan and South Sudan $^{19}$, countries rich in energy resources and minerals. The purpose of these visits, according to Russian Foreign Minister Serghei Lavrov, was to strengthen bilateral political and economic relations and to develop a strategic partnership which is a part of a more consistent Russian penetration in unstable regions, but which are extremely important geopolitically, as well as on the Horn of Africa, the Sahel,

\footnotetext{
${ }^{16}$ http://www.veb.ru/en/strategy/iu/afro/, accessed on 24.09.2014.

${ }^{17}$ Fradkov P, EXIAR: Russian Agency for Export Credit and Investment Insurance, https://www.usrbc.org/pics/File/AM/2011/presentations/Pyotr_Fradkov.pdf, accessed on 24.09.2014.

${ }^{18}$ Vasilenko,S., Russia writes off \$20 billion for African countries, Pravda.Ru, 19.10.2012, http://english.pravda.ru/russia/economics/19-10-2012/122511-russia_africa-0/, accessed on 23.02.2013

${ }^{19}$ Klomegah K.K., Africa: Russia's Investment in Africa - New Challenges and Prospects, http://allafrica.com/ stories/201408211120.html, accessed on 21.04.2014.
} 
northern and central Africa. It should be mentioned that Russia has become a security provider in the Sub Saharan region with peacekeeping troops under the aegis of the UN in the Democratic Republic of the Congo, Ivory Coast, Liberia, Ethiopia, Eritrea, Sudan, South Sudan and the South Western Sahara. At the present time, the Russian Federation has more troops in blue helmets in Sub Saharan Africa than the USA, Great Britain and France together ${ }^{20}$.

In relation to the African countries Russia benefits from the old connections laid down in the time of Soviet Union, from the tens of thousands of civilian and military specialists trained in Russian schools and universities, from the diplomatic and military support the Soviet Union granted to anti-colonial and Non Aligned movement, from the African economic, military, and political networks that span time to today, as well as by the pragmatism with which African leaders appreciate the existence of a competitor to Chinese, Indian or Western offers. Unlike the Chinese, whose presence in Africa has been visible, the Russians have preferred insidious methods, only now coming to light in all their amplitude, and demonstrating that Western afro-pessimism and the global spaces theory that disassociate Sub Saharan Africa from political interest have been the biggest strategic mistakes of the past 20 years.

\section{Are we Witnessing a New Partition of Sub Saharan Africa?}

In July 2014, in Fortaleza, Brazil, the 6th Summit of Emerging Powers took place. Ten extremely interesting meeting conclusions have been summarized by Alecsander Yakovenko, Russian Federation Ambassador in the United Kingdom of Great Britain and Northern Ireland ${ }^{21}$. Among these, two are the most interesting. The first one is related to the establishment of the New Development Bank, NDB, perceived as a counterbalance of the World Bank. The other one concerns the establishment of the Contingent Reserve Arrangement, a reserve fund to protect against certain financial crises which are likely to undermine the economic development of the the emerging powers. NDB headquarters will be based in Shanghai and its main objective will be supporting emerging economies of which are automatically counted the emerging African economies. The philosophy of the BRICS organization, which flows from the decisions compiled by Yakovenko, is the creation of alternative exchange markets which would become a counterbalance to the neo-liberal system and to Bretton Woods-type instruments which have ruled the political and economic-financial world over the last 70 years.

\footnotetext{
${ }^{20}$ Pham P.J., Russia's Return to Africa Two Decades After Pullback, Russia Chases Gas Resources, Minerals and UN Votes, 13.03.2014, http://www.atlanticcouncil.org/publications/articles/russia-s-return-to-africa, accessed on 23.09.2014.

${ }^{21}$ Yakovenko A., 10 major outcomes of BRICS Summit, 21.07.2014, http://rt.com/opedge/174344-ten-outcomes-brics-summit/, accessed on 24.09.2014.
} 
In 2015, Russia will attain the rotating presidency of BRICS. The next BRICS Summit is scheduled for July 2015 in Ufa, capital of the Republic of Bashkorostan. The Russian agenda, according to Yakovenko, will aim to create a strategy of multilateral economic cooperation, a map of cooperation in investments, the creation of associations in the field of energy and energy policies, a fuel bank, cultural cooperation, educational cooperation and a processing center specializing in the metallurgical industry. Professor Georgy Toloraya, department head for Regional Projects of the Russkiy Mir Foundation and chief executive officer CEO of BRICS National Research Committee, said that in the context of current developments in Europe, Russia is obliged to reorient itself and Africa is a priority objective.

If for the People's Republic of China and India, African space is, above all, a source of energy and ores, for Russia things are different. Russia is a leading producer of hydrocarbons and has huge deposits of ferrous and non-ferrous ores. Russia's presence in Africa is more related to the need of maintaining an energy vise on the Europeans by control and distribution of hydrocarbons, of blocking access by competitors to African resources to hold diplomatic advantage which may be used in Ukraine type situations. The subject of the rebuilding of the former Soviet empire is more than just the annexation of ex-Soviet republics but rather the restoration of the Russian sphere of influence. The USSR was a major player in Africa and hidden supporter of the Non-Aligned Movement. We have already seen Moscow's strong orientation toward Africa. Are the BRICS going to be the new Non-Aligned Movement? Will the BRICS become a Russian tool for a new partition of Sub Saharan Africa to Moscow's benefit? The answers are found in Beijing.

In 2013, at the Durban, South Africa, Summit, the BRICS decided to create NDB. The negotiations which have occurred since that date have been related to the percentages that each country would hold as shareholders in the new financial institutions. In September 2013, at the BRICS meeting held in St. Petersburg, Russia, China declared its readiness to allocate $\$ 41$ billion and to host the central headquarters of NDB, while the rest of the $\$ 100$ billion agreed to for NDB would be shared among the remaining participants, specifically, South Africa depositing $\$ 5$ billion, while the Russian Federation, Brazil and India would contribute \$18 billion each $^{22}$. China's determination to become the leader of BRICS was made obvious by their proportion of contributions to the fund, despite the dissatisfaction Brazil and India expressed regarding the algorithm used for the NDB shares ${ }^{23}$.

\footnotetext{
${ }^{22}$ Desai R.M., Vreeland J.R., What the new bank of BRICS is all about, The Washington Post, 17.07.2014, http://www.washingtonpost.com/blogs/monkey-cage/wp/2014/07/17/what-thenew-bank-of-brics-is-all-about/, accessed on 24.09.2014.

${ }^{23}$ Kelly L., Soto A., BRICS may decide on $\$ 100$ billion fund early 2014 - Russia, Reuters, 12.10.2013, http://in.reuters.com/article/2013/10/11/g20-brics-fundidINL6N0I13N720131011, accessed on 24.09.2014.
} 
What do the Chinese leaders think about the Russian proposal to replace the US Dollar with the Russian Rubble as an international currency, as Russian ambassador Vadim Lukov proposed ${ }^{24}$ ? They are certainly not very excited at such a prospect. Tensions within the BRICS are just at the beginning. China is undeniable the leader of the organization, with major interests in Sub Saharan Africa which extend from hydrocarbon resources, uranium and REM, to diamond mines and agricultural land, up to the Lebensraum required by a population on the rise. Russia has become a competitor of China in the Sub Saharan region and a contextual partner in the process of China's success as a superpower. Will China want to share its sphere of influence with another player? It's hard to believe it would. For now, China assumes the role of the "wise old man who stands beside the river and waits", the old concept, Wu Wei, the vigilant waiting. The Beijing leaders know that Moscow is clamped in a vice between Putin's boundless ambitions and geostrategic reality. Russia desperately needs China as an ally in coping with the West.

Conversely, China has no need for Russia other than for its energy resources and minerals ores as well as for its extremely thinly populated Siberian taiga. Rather, China needs Western European markets to maintain its annual eight percent economic growth rate to reduce the population percentage that lives below the poverty level in the center part of the country. As recently as seven years ago some 800 million of that nation's total of 1.3 billion lived in poverty. Undoubtedly, China is the winner in the current Ukrainian crisis because it will be able to put an assortment of questions on the table, with little effort, such as the status of Taiwan, the question of the Diaoyu/Senkaku islands, space exploration, as well as other international trade and customs matters.

The current Russian offensive in Africa is a two-edged sword for Moscow. On the one side there is the rebuilding of the super-power image of the Russian state, while on the other side that charge collides with the interests of three partners of BRICS, i.e. China, India and the SAR. Within a few short years we will see how much cohesion remains among BRICS members.

On the other hand, in 2000, the Clinton Administration laid the foundations of a mechanism for the integration of the African market in the global economy called AGOA - Africa Growth and Opportunity $\mathrm{Act}^{25}$, which is in fact a commercial agreement between the United States of America and 40 African states. The objectives of this agreement are to encourage trade between the parties by granting

\footnotetext{
${ }^{24}$ Samofalova O., BRICS Countries to set up their own IMF, Russia Beyond the Headlines, 14.04.2014.

http://rbth.com/business/2014/04/14/brics_countries_to_set_up_their_own_imf_35891.html, accessed on 24.09.2014.

${ }^{25}$ About the Africa Growth and Opportunity Act (AGOA), The Foundation for Democracy in Africa, http://www.democracy-africa.org/AGOA_Civil_Society_Network.html, accessed on 24.09.2014.
} 
"free access to the US market of products coming from these states, access to credit and to American free technical expertise and (to) encourage reforms and efforts for development". This decision was followed by the building, in effect from the $1^{\text {st }}$ of October 2008, of the United States Africa Command USAFRICOM, ,one of six of the U.S. Defense Department's geographic combatant commands, responsible to the Secretary of Defense for military relations with African nations, the African Union, and African regional security organizations" ${ }^{26}$. In June 2012, the Obama administration published the US strategy toward Sub-Saharan Africa ${ }^{27}$ In this document it is stated that "Africa is more important than ever to the security and prosperity of the international community, and to the United States in particular," and that "the United States will not stand idly by when actors threaten legitimately elected governments or manipulate the fairness and integrity of the democratic processes, and we will stand in steady partnership with those who are committed to the principles of equality, justice, and the rule of law".

In 2013, USA president Barack Obama has made an official visit to Senegal, South Africa, and Tanzania where he announced the decision of some American companies to invest \$ 7 billion into African electrification networks and agriculture. Are these measures sufficient? Obviously not. Obviously, the last 25 post-Cold War years of diminished interest on Sub Saharan Africa by American administrations gave free way to China and Russia. Obviously, American administrations' weak reactions have allowed increasing Russian influence in Europe and increasing energy dependence of the European Union on Russian gas. Maybe reconsideration of restrictions on the export of American gas to Europe and, recognition that SubSaharan Africa as an area of utmost importance to the status quo, as well a new strategy to Africa, would reverse America and the West's declining role in Africa.

Are there going to be new conflicts soon in the Sub Saharan region? It might be possible. The spectrum of unified terrorist organizations operating in Africa in conjunction with the Islamic State of Iraq and the Levant ISIL can be very real. Would the great African players as China, Russian Federation and the USA be able to restrain conflicts after the pattern of those in during the Cold War? Yes, but not in the very near future, whereas the Ukrainian and the Syrian conflicts are limiting their options. It is most likely that, soon, Sub Saharan Africa will become the subject of soft power tools only.

\section{Conclusions}

Sub Saharan Africa is the global space which can ensure the rebuilding of revanchist Russia's sphere of influence and super-power image lost after the dismemberment of

\footnotetext{
${ }^{26} \mathrm{http}: / /$ www.africom.mil/about-the-command, accessed on 24.09.2014.

${ }^{27}$ U.S. STRATEGY TOWARD SUB-SAHARAN AFRICA, June 142012

http://www.whitehouse.gov/sites/default/files/docs/africa_strategy_2.pdf, accessed on 12.10.2014.
} 
the USSR. Aware of Georgia and Ukraine's desire to escape her sphere of influence, the Russian Federation has prepared herself for the time when relations with the West will once again freeze into a Cold War. Since 2008, immediately after the conclusion of the Georgian crisis, Russia has sought to make the EU increasingly dependent upon Moscow's gas and pipeline system. Control of the Trans-Saharan gas pipeline is such a tactic, as well as Russian dominance of the Algerian gas fields. The consistent and determined strategy toward reestablishment of traditional Russian spheres of influence aims, additionally, to an increase in the number of favorable African votes in the UN General Assembly for Russian positions and to extend control over as many African resources as possible.

To achieve these goals the Russian are employing a wide range of hybrid type tools. Recent news which has burst out in the Nigerian press regarding the financing of the terrorist organization Boko Haram by president Jonathan's intimates, and of the Nigerian government's decision to ask for Russian military expertise in counter terrorism due to a lack of Western support, even indirectly links to Russia. On the other hand, Russia wants to become the BRICS leader and to make use of that organization as a platform of its re-affirmation as a great power. But, the distance between aims and geostrategic reality is very great, indeed, over which both China and the USA both present many obstacles. Furthermore, the Ukrainian crisis and the cooling of the relations between the West and the Russian Federation will have echoes both in Sub Saharan Africa, as well as in the Taiwan and Diaoyu/Senkaku Islands disagreements. Possible African developments, in the wake of the Ukrainian and Syrian crises, could vary from the broadened use of soft power tools, to major instabilities generated by an alliance of terrorist organizations Boko Haram and $\mathrm{Al}$ Shabab to ISIL, as well as the possibility of new bipolar-type conflicts in the medium and long term. This work was possible with the financial support of the Sectoral Operational Programme for Human Resources Development 2007-2013, co-financed by the European Social Fund, under the project number POSDRU/159/1.5/S/138822 with the title "Transnational network of integrated management of intelligent doctoral and postdoctoral research in the fields of Military Science, Security and Intelligence, Public order and National Security - Continuous formation programme for elite researchers - "SmartSPODAS".

\section{References:}

About the Africa Growth and Opportunity Act (AGOA) 2015. The Foundation for Democracy in Africa. At http://www.democracyafrica.org/AGOA_Civil_Society_Network.html;

Agande, B. 2014. BOKO HARAM: FG turns to Russia, China as USA, UK fail Nigeria, http://www.vanguardngr.com/2014/09/boko-haram-fg-turns-russia-china-usa-uk-failnigeria/;

Cohen, A. 2009. Russia's New Scramble for Africa, Moscow attempts to rebuild its sphere of influence in the African continent. Wall Street Journal Europe.

Desai, R.M., Vreeland, J.R. 2014. What the new bank of BRICS is all about. The 
Washington Post at http://www.washingtonpost.com/blogs/monkeycage/wp/2014/07/17/ what-the-new-bank-of-brics-is-all-about/;

Exposing the CBN Boko Haram "sponsor". 2014. http://www.vanguardngr.com/2014/09/exposing-cbn-boko-haram-sponsor/;

Folawiyo, Y. 2015. Nigeria in a lame trans-Saharan gas pipeline deal with Gazprom, Money Worth, http://www.moneyworth.com.ng/nigeria-in-a-lame-trans-saharan-gaspipeline-deal-with-gazprom/;

Fradkov, P, 2011. EXIAR: Russian Agency for Export Credit and Investment Insurance. At https://www.usrbc.org/pics/File/AM/2011/presentations/Pyotr_Fradkov.pdf;

http://www.africom.mil/about-the-command/;

http://africacenter.org/security/experts/assis-malaquias/;

http://www.veb.ru/en/strategy/iu/afro/;

In Algeria, drilling work on the new well begins, Gazprom International, 2014. At http://www.zargaz.ru/en/news-media/articles/algeria-drilling-work-new-wellbegins;

Kelly, L., Soto, A. 2014. BRICS may decide on $\$ 100$ billion fund early 2014. Russia, Reuters at http://in.reuters.com/article/2013/10/11/g20-brics-fundidINL6N0I13N720131011;

Klomegah, K.K. 2014. Africa: Russia's Investment in Africa - New Challenges and Prospects. At http://allafrica.com/stories/201408211120.html;

Neuhauser, A. 2014. With World Watching Ukraine, Russia Makes Energy Moves in Africa,U.S.News \& World Report. At http://www.usnews.com/news/articles/ 2014/04/25/with-world-watching-ukraine-russia-makes-energy-moves-in-africa;

NNPC 2010. A pipeline of opportunities, Pipelines International, http://pipelinesinternational.com/news/nnpc_a_pipeline_of_opportunities/041509/;

Pham, P.J. 2014. Russia's Return to Africa Two Decades After Pullback, Russia Chases Gas Resources, Minerals and UN Votes. At http://www.atlanticcouncil.org/ publications/articles/russia-s-return-to-africa;

Phillips, A. 2014. South Africa and Russia sign Multi-Billion Rand Nuclear Reactor Deal. At http://www.africanbusinessreview.co.za/technology/1689/South-Africa-and-RussiaSign-Multi-Billion-Rand-Nuclear-Reactor-Deal;

Powell, G. 2014. Australian Stephen Davis risked life in attempt to rescue kidnapped Nigerian girls, http://www.abc.net.au/news/2014-08-27/australian-risks-life-torescue-kidnapped-nigerian-girls/5699676;

Rosatom signs international deals, 2012. World nuclear news. At http://www.world-nuclearnews.org/NN_Rosatom_signs_international_deals_0406121.html;

Russia, Nigeria sign nuclear deal, 2009. At http://www.upi.com/Business_News/ EnergyResources/2009/03/20/Russia-Nigeria-sign-nuclear-deal/UPI-24901237578334/;

Samofalova, O. 2014. BRICS Countries to set up their own IMF, Russia Beyond The Headlines.

Vasilenko, S. 2012. Russia writes off $\$ 20$ billion for African countries, Pravda, Russia. At http://english.pravda.ru/russia/economics/19-10-2012/122511-russia_africa-0/;

Visit of Gazprom International Head to Algeria, 2014. Gazprom International. At http://www.zargaz.ru/en/news-media/articles/visit-gazprom-international-headalgeria;

U.S. Strategy Toward Sub-Saharan Africa, 2012. At http://www.whitehouse.gov/sites/default/files/docs/africa_strategy_2.pdf;

Yakovenko, A. 2014. 10 major outcomes of BRICS Summit. At http://rt.com/opedge/174344-ten-outcomes-brics-summit/; 